\title{
Can IT Industry Merger and Acquisition Effect on Brand Equity of Their Product/Services? A Case Study from Qatar
}

\author{
${ }^{1}$ Habib Ullah Khan and ${ }^{2}$ Mahmood A. Awan \\ ${ }^{1}$ College of Business and Economics (CBE), Qatar University, Doha, Qatar \\ ${ }^{2}$ SolBridge International School of International Business, Daejeon, South Korea
}

\begin{abstract}
A combination of assets and liabilities when associated to a brand which provides additional value to the specific product and/or service is brand equity. Branding is used as a means to arrive at a conclusion and decision about the product or service. Brand equity has gained a great deal of attention in the marketing literature and hence, many definitions of brand equity have been put forward. This study reveals the relationship and effect of brand equity before and after merger and acquisition amongst organizations. The major acquisitions and mergers of two technological giants: Microsoft-Skype technologies and Facebook-WhatsApp instant messaging application are considered for this study. In the present world where technology is growing by leaps and bounds, there is every need to understand and analyze the relationship and effect of these mergers and acquisitions from the perspective of perceived brand value of customer. The purpose of this study is to establish a relationship between brand equity after the M\&A and the customer loyalty. Also, the study aims to identify the drivers of brand equity for technologically advanced organizations. A total of 509 sample surveys are collected for this purpose from the students of Qatar University by random sampling method. It is hence, revealed that the effect of brand awareness and perceived brand value are the important origins of brand equity. Results also show that the significance of perceived brand value when compared to that of total effect is four times higher than the brand awareness. Significant theoretical and managerial contributions to brand equity are noticed from the organizations before and after mergers and acquisitions in many ways. Apart from these, product and service functionality are also identified as important components which drive the brand awareness and brand value directly and explain the indirect relationship towards brand equity. Post the merger and acquisition of organizations from the customer perspective the acquired organization is required to develop and integrate the companies involved in order to resolve the technical complexities of product and service related issues. These organizations are supposed to extend support to others within the acquisition to foster confidence among the customers of the new firm. By basing on these inferences, the management is required to take into consideration and focus its efforts on the tasks and activities to be implemented at this juncture. Few of the tasks that can be implemented include, the feasibility operations to improve the customer service, increase the customer's identification on brand awareness and perceived brand value apart from managing resource allocation and training needs within organizations. Thereby, based on the results of this study, it is evident that the merger and acquisitions of the companies help them to enhance the brand equity.
\end{abstract}

Key words: Brand equity, mergers, acquisitions, online mergers, IT mergers, customer service

\section{INTRODUCTION}

Branding is positioning of a product and service in the thoughts of the customer that adds value to the services and there by provide consulting and managerial facilities (Awan et al., 2012; Khan, 2016; Gholami, 2017). Keller and Lehmann (2003) state that brand equity reflect customer's feeling and their purchasing preferences of product and service. Brand equity as defined by Aaker (1991) states that it is the set of assets and liabilities of a brand, name, symbol that are added to the value of a product or service of a firm and its customers. It also has significant effect on the prices and profits obtained in the market and there by helps to improve the capitalization prospects of the organization, owning the brand.

The conceptual foundations of the brand equity refer to the applicability across various contexts including 'B2C' and 'B2B' markets (Biedenbach and Marell, 2010; Khan, 2013b; Najmi et al., 2015). The assets of brand equity as per Aaker (1991) are brand loyalty, brand

Corresponding Author: Habib Ullah Khan, College of Business and Economics (CBE), Qatar University, Doha, Qatar 
awareness, perceived value, brand association and other brand assets. According to Khan et al. (2014a, b) the indicator of state of heath of brand is the brand equity.

Ho et al. (2016) stated that brand is closely connected to the brand the perceived quality of the customer and such perception indicates total quality which is not necessarily based on customer's know-how about detailed characteristics of the product and service. The trend which is obvious in recent times is the acquiring firms which have successful brands are trying to avoid high costs and risks associated with new service launch and product development. A study by Awan et al. (2012) revealed the issues resulted as an outcome of positive effects of brand equity on profits and prospective cash inflows, customer's willingness to shell out money for premium payment. The decision made on merger and acquisition leads to dynamic changes in the forecasting of stock market trends of the commodities as organizations with their brands yield competitive advantage and thereby leads to success.

According to Awan et al. (2012), the advantages of merger and acquisitions are many from cost efficiency through economies of scale, thereby enhancing revenue through obtaining profits in market share and hence by tax gains. The primary benefits identified are focused on the brand value, improved efficiency in cost of commodity, abundance in market gain on shares and debentures. The pivotal role for all the outcomes detailed above is on the account of the 'perceived' benefits of merger and acquisition of the organizations.

In a study conducted by Khan and Awan (2017), merger and acquisitions of companies and organizations aid them to procure and adapt advanced technologies, services, products, various marketing and distributing channels and adopt technologically advanced logistics chains in order to obtain a desirable position in the market. According to Smuts et al. (2017), the 4 strategic reasons identified for fostering brand equity are positioning, gap filling organizational competencies, broader and stronger access to markets.

In a study conducted by Allaway et al. (2011), regarding the brand equity, it is opined that the brand with positive equity will yield high strategic value with advantages of higher margins, opportunities of extending the brand value and perception. This provides a shield against the potential competitors in addition to tough and sturdy preferences of the customer organization's purchase processes and the consumer's loyalty. According to Keller and Lehmann (2003), brand equity is built based on the design of the brand elements like memorability, meaningfulness, aesthetic appeal, transferability (both within and across product categories and across geographical and cultural boundaries and market segments) also, adaptability and flexibility over time and not the least to mention is the legal and competitive protection ability and defensibility of these elements is accrued as a result of brand equity initiatives. Each of these elements has their own pros and cons. As per Keller (2003a, b), the most required element to brand equity is the mixture and balance between different elements in their verbal and visual context to maximize their collective contribution.

Simon and Sullivan (1993) have proposed two major approaches in defining the brand equity-financial and customer perspectives. The financial perspective talks in detail about the value of a brand to the firm that is from the organizational overview while 'customer perspective' describes brand equity as the value attributed by the brand to the customer. Most of the researches in this field have supported the customer perspective approach and are in favor of the customer's opinion of measurement of brand equity. According to Cobb-Walgren et al. (1995), the value of an investment is provided to a customer with the brand through the product. This applies to manufacturers, retailers, distributors both internal and external customers in the logistic chain only if there is value for the customer's perception about the brand.

The value of merger and acquisition globally is reported as $\$ 599.1$ billion and the technology contributes to around $\$ 54.3$ billion in the first quarter of 2014 as reported by 'Merger Market'. The two giants involved are Microsoft acquiring Skype technologies and Facebook acquiring WhatsApp are the recent M\&A (Khan et al., 2013; Heang and Khan, 2015; El Halabi et al., 2014; Hassan et al., 2016) Skype technologies is acquired by Microsoft for more than $\$ 8.56$ billion by cash and Facebook acquired Whats App for around $\$ 22$ billion also in cash the biggest acquisition ever.

Brand recognition and brand awareness are important sources of brand equity (Rios and Riquelme, 2010)). Brand recognition plays a major role and is a direct contributor of brand equity but indirectly influences the customers. However, elements such as trust and loyalty always override the impact of these relationships. Brand awareness is identified as the ability of the customers to recognize the brand and recollect it in various situations as mentioned by Awan et al. (2012). Aaker (1991) also emphasizes four major brand equity dimensions such as brand loyalty, brand awareness, perceived quality and brand associations. Assets such as trademarks, channel relationships, patents are the supporting category for brand equity dimensions (Biedenbach and Marell, 2010; Khan, 2013b; Khan et al., 2014a, b; Askoul et al., 2016). 
Brand equity for technologically advanced organizations needs more research to be conducted as against the access of academic literature for other organizations on merger and acquisitions. The current research identifies the effects of brand equity on merger and acquisitions on the information technology based companies which provide online services and products.

This study also examines the customer's attitude towards brand equity after M\&A. The survey elaborated about the customer's feeling on the M\&A of these two brands as a result of Microsoft acquisition with Skype technologies and Facebook acquisition with WhatsApp. The balance theory is useful in detailing the customer's attitude formation and change. Balance theory is applied to arrive at the hypothesis for this study. The brand awareness indicates consumer's capability to identify the brand and its perceived value (Biedenbach and Marell, 2010; Awan and Khan, 2016; Khan, 2016)

As both these organizations-Skype technologies and WhatsApp are technologically advanced application and product oriented organizations, there is a significant difference in studying and understanding the brand equity of these organizations before and after merger and acquisition. This study is organized with various elements starting from literature review, hypothesis, research methodology adopted for this research and analysis part. The findings are detailed along with conclusions and limitations.

Literature review: In the competitive world, brand and brand equity are used synonymously to identify the organization. According to Rios and Riquelme (2010), these terms are used interchangeably in the business environment and the mix for brand equity is specific to the domain. Aaker (1991) identified five constructs of brand equity-brand awareness, brand image, brand salience, service quality and band loyalty. These concepts are also applied to various other sectors such as tourism where the brand equity plays a vital role (Khan, 2012).

The fact remains that according to customer, brand equity is the mix of perception and value of the service and product added to it along with the good will of the brand. This stands as a unique identity and is the sole bread winning parameter for the organization (Khan, 2013b; Musa et al., 2015). Along with the passing of time, various concepts related to combination of brand equity and technology have emerged making the process of brand management a complex artifact (Hamzah et al., 2014; Brock and Khan, 2017a, b). Keller in his studies has described the dimensions of brand equity as brand image based on favorable and unique associations, brand awareness with brand recognition and recall. These models highlight the knowledge structures developed by customers affecting the behavior and choice of better services and goods in the market.

Yoo et al. (2000) affirmed that internal factors like mergers and acquisitions play a significant role on the brand equity of the organization and companies incur high costs on account of neglecting these perceptions of the customers. Though brand equity on one hand provides foundation concepts for making strategic decisions on mergers and acquisition, on the other hand, it also helps in assessing and forecasting the brand equity which is the required element for organizations to design the future mission and thereby the business plans (Khan et al., 2017a, b; Bashir and Khan, 2016; Hassan et al., 2015). Srinivasan et al. (2015) in their studies mentioned that brand equity consists of components which are both the attributable and non-attributable based elements. The major components which influence brand equity are functionality, awareness, customer service and perceived value. Apart from these, brand equity dimensions include brand awareness, perceived quality, brand association, brand image and brand loyalty (Omonaiye et al., 2015; Bashir and Khan, 2016).

Functionality: Hamzah et al. (2014) defined the functionality of a brand as the combination of skill, knowledge, freedom, attention, focus and interactivity. Ho et al. (2016) stressed the importance of the functionality of the brands for the organizations before and after the merger. Companies are required to assess the functionality from the concept of the service delivery and ease of use. A study carried by Ratnatunga and Ewing (2009) revealed that brand equity needs to be given adequate significance and prominence in mergers and acquisitions. Ho et al. (2016) affirmed their findings on the customer's view about the brand equity with respect to its constructs and aid to the management in strategic decision making.

The study conducted by Gordon (2010), reveals the fact that customer's response is both positive and hostile for the brands and their product associations. These responses include functionality and evaluation of the brand and the portrayal of the brand from the customer's perspective. Such responses collectively form the customer's disposition on the brand. On the whole, customer's thought process is influenced by the knowledge of the brand and its functionality (Khan and Gadhoum, 2018). The significance of technology and its interactiveness with brand equity from customer's perspective is highlighted by Klaus and Maklan (2013). 
In general the low quality brands tend to benefit more from the merger and acquisition, brand associations. At the same time, high quality brands also benefit from the addition of incongruent and inferior quality and functionality of the substandard brands. These insights in the relationship are highlighted by Gill and Lei (2009). There is a dearth of research and studies to be conducted on brand equity in mergers and acquisitions of the product and services. So, studies should be conducted in these lines (Yoo et al., 2000). Over the years, the management has become more concerned on the functionality of the product and service in the branding (Biedenbach and Marell, 2010; Khan and Awan, 2017; Smuts et al., 2017). But in case of technologically advanced organizations, confidence and knowledge about the services is nurtured by functionality which in turn develops brand equity (Rios and Riquelme, 2010; Ho et al., 2016; Bankole et al., 2017; Khan et al., 2017b).

While mentioning brand image from tourism point of view, Lee et al. (2011) revealed the 3 vital dimensions as attractiveness of the destination, functionality and ambience. It is also found from their research that these are all correlated.

Awareness: As per Aaker (1991), awareness is another important construct of brand equity. The most important element of brand awareness is the brand name recognition and hence creation of brand awareness is the first step towards brand equity (Awan et al., 2016). Awan et al. (2012) emphasized prominent reasons for studying the brand equity in mergers and acquisitions of companies. They mentioned that brand equity is not only beneficial to comprehend the level of brand awareness for the customer but also helps to make strategic decisions and to forecast the financial outcome of the customer oriented ventures.

Rios and Riquelme (2008) in their study mentioned that brand awareness play a vital role especially strategic studies in the tourism sector thereby enhances the name and attributes of the brand during decision making even by the customer. It is mentioned that the advantage of brand awareness for the customer acts as an insulation against tough competition and potential competitors in the market and ensures them to pay higher for the services and products than their counterparts (El Halabi et al., 2014; Khan, 2012; Das and Khan, 2016). According to Ho et al. (2016), the customers are convinced of the quality of the product and services primarily on account of brand awareness. This causes the brand equity to grow as well. The intricacies of brand awareness are well developed by Ho et al. (2016). So by and large, it is proposed that brand strength in the consumer's mind is referred to as brand awareness (Yoo et al., 2000; Khan and Ejike, 2017)

Brand awareness is one of the components of brand equity and it enhances and strengthens the relationship with the customers through the brand value thereby enabling the customers to accept the organization's decision and strategy on further growth and promotion of the product and services while discussing from the perspective of customer awareness, Casalo et al. (2010) mentions that customer's level of knowledge plays a crucial role in improving brand equity.

Consumer behavior is influenced and governed by brand awareness and brand associations. This validates the task of focusing the market mix in order to achieve the objectives of widening the brand awareness concept, enhancing the brand image by the organization. Research conducted by Gordon (2010) reveals that the studies which can elaborate the understanding of customer's cognition and responses directly impact brand equity, apart from these, these studies should also provide adequate pathway and focused approach as a directive for academicians and practitioners on enhancing the brand equity.

Customer service: Bamert and Wehrli (2005) proposed in their study that customer service is a functional dimension of perceived service quality and is visualized as a marketing activity which influences brand equity. Customer service is identified as one of the most significant constructs for effective communication in the markets. The studies pertaining to customer oriented brand equity are found to be scanty especially pertaining to the web based technology (Awan et al., 2012; Rios and Riquelme, 2010; Khan and Adediji, 2017).

Ho et al. (2016) affirmed that in order to increase the brand differentiation and image in higher education, the concept of customer service should be highlighted and stressed more than that of the service transactions and hence leading to wider perspectives of customer service delivery models. The concerns which arose on account of mergers and acquisitions are addressed effectively by focusing on the customer service. There by the strategy towards the customer service yield better results and help business to soar irrespective of the decision of the management on mergers and acquisitions. Awan et al. (2012) found by their study that the sole reason attributed for the above said situation is on account of the brand image in the customer's perspective and the favoritism towards the brand and constitutes brand equity.

Ho et al. (2016) stated that customers can be benefited by the service provided by the organizations 
through technological up gradation and enhancing the customer's knowledge on new services which can be made possible by suitable augmentations and promotional campaigns. One of the studies conducted by Alwi and Kitchen (2014) revealed that the best way to create and sustain brand differentiation and brand equity is to focus and broaden the purview of service transactions apart from sheer customer service. Khan and Awan (2017) in their research emphasized that the knowledge developed by those customers who use complex services online can come across with complex barriers which affect the customer-firm relationship. For the customers who have developed the knowledge to use complex services through the online channels, the customer's perceived value may have a bigger impact on loyalty towards the service provider.

Apart from this, they also added that in technologically advanced corporations where all the transactions are online, advanced technologies such as virtual agents play a vital role in resolving the customer's concerns effectively with a human touch and thereby creating a niche in the market. To summarize this concept of value based strategies, enhancing the customer response and satisfaction for all the products and services there in delivered by the organizations researches well (Khan and Alhusseini, 2015; Khan and Uwemi, 2018a, b). It is also suggested that organizations are required to adopt the best customer service practices and should understand the customer's purchasing intentions which aid the corporations to increase the profitability and to sustain in the competition with an added advantage of customer support. Beerli et al. (2004) in their research revealed that customer satisfaction is obtained as a result of benchmarking and comparing the expected and actual brand performance with perceived performance at a cost paid to achieve the objective. In simple, it can even be understood that the overall customer satisfaction is the customer's feeling and perception received from the supplier (Khan et al., 2016).

Perceived value: Gill and Dawra (2010) proposed a concept of perceived value which forms an important construct for the mix of brand experience. In a multi-channel context mentioned by Ho et al. (2016) it is affirmed that customer service and perceived value of offline services is much more than that of online services. Orthodoxically, the traditional offline services form the foundations to customer relationships and thereby the brand equity. Hassan et al. (2016) in their study analyzed around 260 customers to understand the role of perceived value as a mediator in decision making process of procurement and proved that the perceived value played a major role and influenced the brand equity.

Perceived quality is defined by Zeithaml (1988) as the significance of product quality to competitors excluding the technical component. Perceived quality of the customer in combination with brand loyalty has a significant effect on decision making exclusively for the requirement of procurement management. The effects of perceived value are discussed by Yoo et al. (2000) in a case of merger of a brand. They opined from their study that in case of a merger of a low brand image with that of a higher brand image company or a product or a service, the perceived value of the low image goes up in accordance with the merged ones. Ho et al. (2016) in their studies mentioned that core 'Customer Based Brand Equity' (CBBE) are the primary predictors of brand purchase and the purchase intent and behavior are governed by perceived quality, perceived value for the cost, uniqueness and willingness to pay the premium price for a brand as stated by Aaker (1991).

In a study done by Rios and Riquelme (2010), regarding the branding strategies for technologically advanced companies, it is mentioned that the customer perceived value researches as an antecedent for branding strategies of internet based companies. Gill and Dawra (2010) established from their research that developing the brand awareness, nurturing quality consciousness and value creation forms the pre requisites for building the brand equity. In order to increase the perceived value of the divested brand, $\mathrm{Vu}$ and Moisescu (2013) stated that comparison between the offers and playing bidders off against each is found to be much beneficial.

Ho et al. (2016) added that 'Customer Based Brand Equity' is formed by six formative dimensions such as past brand loyalty, current brand awareness, current perceived quality, current perceived value for the cost, current brand associations and proprietary asset, uniqueness and three reflective dimensions-future price premium, future brand loyalty and brand emotions.

Having done the limited literature review from the sources and having understood the nomology of the concepts, the following model has been designed for the furtherance of the study (Fig. 1).

Hypothesis development: The proposed hypothesis for this study are:

- $\mathrm{H}_{1}$ : as per customer's perception, the functionality of the products caused a significant increase in the influence on brand awareness, after the M\&A 

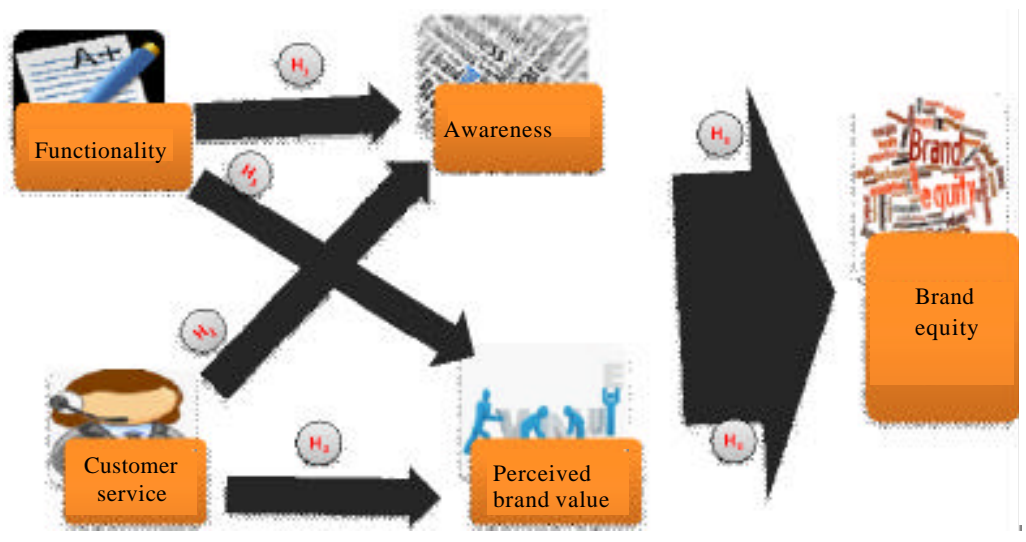

Fig. 1: Model of perceived value

- $\mathrm{H}_{2}$ : as per customer's perception, the functionality of the products caused a significant increase in the influence on perceived brand value, after the M\&A

- $\mathrm{H}_{3}$ : as per customer's perception, the customer service of the alliance companies caused a significant increase in the influence on brand awareness, after the M\&A

- $\mathrm{H}_{4}$ : as per customer's perception, the customer service of the alliance companies caused a significant increase in the influence on perceived brand value, after the M\&A

- $\mathrm{H}_{5}$ : as per customer's perception, the brand awareness of the products caused a significant increase in the influence on brand equity, after the M\&A.

- $\mathrm{H}_{6}$ : as per customer's perception, the perceived brand value of the product caused a significant increase in the influence on brand equity, after the M\&A

\section{MATERIALS AND METHODS}

Data collection process: For the sake of verifying the consistency of our empirical tests, we conducted two surveys in order to collect consumer's responses. The empirical test of the theoretical model has been conducted by using data collected through a survey submitted to a sample of university students. The survey has been designed by using real examples. Specifically, a first version of the survey employed the "Facebook and WhatsApp" case while in a second version we employed the "Microsoft and Skype" case. Such merger and acquisition (M\&A) commercial activities have been considered suitable to our study because those four companies are international companies and respondents can evaluate the brand equity of those companies easily. Respondents were randomly assigned to one of the two versions of the questionnaire.
Respondents: We chose university students in Qatar (undergraduate level) as our respondents in order to increase homogeneity of the sample and to minimize random error caused by selecting the general public (Calder et al., 1981). Students completed the surveys as a partial fulfillment of their courses. We obtained two hundred and seventy-six surveys in total. After excluding invalid survey, 200 and 35 valid surveys were kept for this study. $45 \%$ of the respondents were male $\left(n_{M}=\right.$ $105)$ and $55 \%$ of the respondents were female $\left(n_{F}=\right.$ 130). The ratios of sample size to survey items (15 items) for the sample satisfies the minimum requirements specified by both Gorsuch (1983) and Thompson (2000).

Measures and procedures: For both the versions of surveys, participants completed a questionnaire which has a company logo, name and its brief introduction of M\&A of acquirer and acquired company. To ensure reliability and validity, the measurement items were adapted from the basis of the previous studies. All measures employed in the two versions of surveys are 5-point Likert scale, ranging from 1 (strongly disagree) to 5 (strongly agree). In the real surveys in order to measure product functionality, the items are used from Suppehellen and Nysveen (2001). Consumer service has been measured by using the items by Burke (2002). To measure brand awareness, the scale developed by Yoo et al. (2000) is followed. To measure perceived brand value, the scale of Sweeney and Soutar, (2001) is used. Lastly, brand equity is measured by means of a scale developed by Yoo et al. (2000). For the sake of consistencies, easy understanding and context fitness of the measurement items, a pilot test was implemented recruiting 50 respondents to pretest the reliability, convergent validity and discriminant validity. All the measurement items showed the fitness of the employed 
Table 1: Assessment of internal consistency and convergent validity

\begin{tabular}{|c|c|c|c|}
\hline Variables & $\begin{array}{l}\text { Cronbach's } \\
\text { alpha }(\alpha)\end{array}$ & $\begin{array}{l}\text { Composite } \\
\text { Reliability (CR) }\end{array}$ & $\begin{array}{l}\text { Average Variance } \\
\text { Extracted (AVE) }\end{array}$ \\
\hline \multicolumn{4}{|l|}{ Facebook (F): } \\
\hline Functionality & 0.89 & 0.93 & 0.83 \\
\hline Consumer service & 0.94 & 0.97 & 0.94 \\
\hline Awareness & 0.94 & 0.96 & 0.89 \\
\hline Perceived value & 0.91 & 0.94 & 0.85 \\
\hline Brand equity & 0.94 & 0.96 & 0.86 \\
\hline \multicolumn{4}{|l|}{ WhatsApp (W): } \\
\hline Functionality & 0.78 & 0.87 & 0.70 \\
\hline Consumer service & 0.92 & 0.96 & 0.93 \\
\hline Awareness & 0.93 & 0.95 & 0.88 \\
\hline Perceived value & 0.92 & 0.95 & 0.87 \\
\hline Brand equity & 0.94 & 0.96 & 0.85 \\
\hline \multicolumn{4}{|l|}{ Micr osoft (M): } \\
\hline Functionality & 0.90 & 0.94 & 0.84 \\
\hline Consumer service & 0.94 & 0.97 & 0.94 \\
\hline Awareness & 0.94 & 0.96 & 0.90 \\
\hline Perceived value & 0.95 & 0.96 & 0.91 \\
\hline Brand equity & 0.95 & 0.96 & 0.87 \\
\hline \multicolumn{4}{|l|}{ Skype (S): } \\
\hline Functionality & 0.93 & 0.96 & 0.88 \\
\hline Consumer service & 0.91 & 0.96 & 0.92 \\
\hline Awareness & 0.93 & 0.95 & 0.88 \\
\hline Perceived value & 0.93 & 0.96 & 0.89 \\
\hline Brand equity & 0.95 & 0.96 & 0.87 \\
\hline
\end{tabular}

Table 2: Assessment of discriminant validity, Facebook

\begin{tabular}{llllllll}
\hline Variables & Mean & SD & A & BE & C & E & PV \\
A & 4.03 & 1.14 & 0.94 & - & - & - & - \\
BE & 2.93 & 1.20 & 0.28 & 0.93 & - & - & - \\
C & 2.96 & 1.13 & 0.23 & 0.44 & 0.97 & - & - \\
F & 3.32 & 1.19 & 0.40 & 0.75 & 0.44 & 0.91 & - \\
PV & 3.31 & 1.03 & 0.52 & 0.65 & 0.48 & 0.72 & 0.92 \\
\hline
\end{tabular}

Table 3: Assessment of discriminant validity; Microsoft

\begin{tabular}{llllllll}
\hline Variables & Mean & SD & A & BE & C & E & PV \\
\hline $\mathrm{A}$ & 4.03 & 1.20 & 0.95 & - & - & - & - \\
BE & 3.57 & 1.10 & 0.69 & 0.93 & - & - & - \\
C & 3.31 & 1.05 & 0.48 & 0.62 & 0.97 & - & - \\
F & 3.90 & 1.03 & 0.81 & 0.79 & 0.65 & 0.91 & - \\
PV & 3.75 & 1.05 & 0.79 & 0.77 & 0.56 & 0.83 & 0.95 \\
\hline
\end{tabular}

construct and we adopted those measurement items into formal empirical tests. Table 1 shows assessment of internal consistency and convergent validity. In the formal empirical test as indication in Table 1, our Cronbach's alphas $(\alpha)$ for all the constructs are above 0.6 that is considered as an acceptable level (Bagozzi and $\mathrm{Yi}$, 1988). All items of Composite Reliability (CR) exceed the threshold value of 0.7 of internal consistency (Fornell and Larcker, 1981). In addition, the Average Variance Extracted (AVE) values are above recommended threshold value 0.5 for all constructs (Fornell and Larcker, 1981). Therefore, convergent validity is accepted.

The study measures the discriminant validity employing the test suggested by Fornell and Larcker (1981). Good discriminant validity is represented as all square roots of the AVE, diagonal elements in Table 2-5 are greater than the correlations between constructs. Table 2-5 shows the mean and Standard Deviations (SD) and assessment of discriminant validity of each construct.
Table 4: Assessment of discriminant validity; WhatsApp

\begin{tabular}{llllllll}
\hline Variables & Mean & SD & $\mathrm{A}$ & $\mathrm{BE}$ & $\mathrm{C}$ & $\mathrm{E}$ & $\mathrm{PV}$ \\
\hline $\mathrm{A}$ & 4.29 & 1.08 & 0.94 & - & - & - & - \\
$\mathrm{BE}$ & 3.73 & 1.13 & 0.57 & 0.92 & - & - & - \\
$\mathrm{C}$ & 3.29 & 1.19 & 0.28 & 0.43 & 0.96 & - & - \\
$\mathrm{F}$ & 3.98 & 1.02 & 0.68 & 0.74 & 0.48 & 0.83 & - \\
$\mathrm{PV}$ & 3.78 & 1.04 & 0.69 & 0.73 & 0.39 & 0.79 & 0.93 \\
\hline
\end{tabular}

Table 5: Assessment of discriminant validity; Skype

\begin{tabular}{llllllll}
\hline Variables & Mean & SD & A & BE & C & E & PV \\
\hline $\mathrm{A}$ & 3.76 & 1.20 & 0.89 & - & - & - & - \\
$\mathrm{BE}$ & 2.91 & 1.14 & 0.37 & 0.87 & - & - & - \\
$\mathrm{C}$ & 2.96 & 1.06 & 0.43 & 0.70 & 0.91 & - & - \\
$\mathrm{F}$ & 3.23 & 1.09 & 0.53 & 0.67 & 0.59 & 0.85 & - \\
$\mathrm{PV}$ & 3.23 & 1.06 & 0.52 & 0.56 & 0.58 & 0.78 & 0.89 \\
\hline
\end{tabular}

$\mathrm{A}=$ Awareness; $\mathrm{BE}=$ Brand Equity; $\mathrm{C}=$ Customer service; $\mathrm{F}=$ Functionality; PV = Perceived Value; Diagonal elements represent the square root of AVE for each construct; Off diagonal elements are correlations among constructs

\section{RESULTS AND DISCUSSION}

We used AMOSTM 22 Software to perform 4 multi-group path analyses to test our conceptual model, respectively. In terms of the indices of model fit, the values of Goodness of Fit (GFI), Comparative Fit Index (CFI) and Incremental Fit Index (IFI) were above 0.9 (Bagozzi and Yi, 1988). The Root Mean Square Error of Approximation (RMSEA) which is another important index of measurement of fit also had a value of $<0.5$, representing a good model fit. This is a saturated model and therefore it fits the data perfectly. However, some of the hypothesized paths were found to be non-significant at the 5\% significance level. After sequentially fixing the non-significant parameters in each sample to zero, we ended up with the models shown in Fig. 3 and 6. These models are constrained versions of the theoretical model displayed in Fig. 2 with some direct paths fixed to zero. The fits of the resulting sample model are excellent. The result of each company shows that our p-value $\chi^{2}$ (Chi-square test) is larger than 0.05 (Facebook: $\chi^{2}(9)=$ $3.56, \mathrm{p}=0.062$; GFI $=0.98$; $\mathrm{CFI}=0.98 ; \mathrm{FI}=0.98$; RMSEA $=0.04$; WhatsApp: $\chi^{2}(8)=3.143, \mathrm{p}=0.075$; GFI $=$ 0.96; CFI $=0.98 ; \mathrm{FI}=0.98 ;$ RMSEA $=0.01 ;$ Microsoft: $\chi^{2}(10)=4.01, \mathrm{p}=0.053 ; \mathrm{GFI}=0.99 ; \mathrm{CFI}=0.99$; IFI $=0.99 ;$ RMSEA $=0.03$; Skype: $\chi^{2}(9)=4.036, \mathrm{p}=0.091$; $\mathrm{GFI}=0.98 ; \mathrm{CFI}=0.97$; IFI $=0.98 ; \mathrm{RMSEA}=0.03$ ). Consequently, all descriptive goodness of fit indices are very high.

Table 6 describes the empirical results of before/after M\&A of each company. Table 6 , the effect of product functionality on brand awareness for each company is significant for both before and after M\&A. However, the effects of after M\&A are larger than before M\&A only happened in Facebook and WhatsApp not in Microsoft and Skype $\left(\right.$ F-Func $_{\mathrm{A}(\text { Before })}=0.38, \mathrm{p}<0.01, \mathrm{~F}-$ Func $_{\mathrm{A}(\text { After })}=0.44$, 


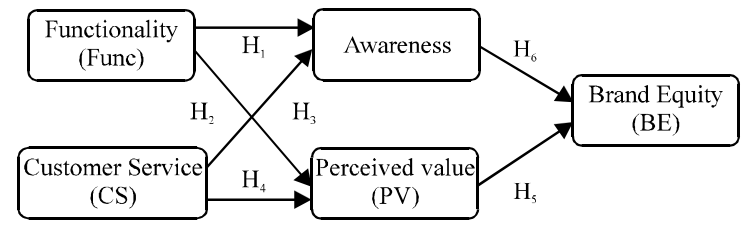

Fig. 2: Empirical model

\begin{tabular}{|c|c|c|c|c|c|c|}
\hline \multirow{2}{*}{ Hypothesis } & \multirow{2}{*}{$\begin{array}{l}\text { Proposed } \\
\text { path }\end{array}$} & \multicolumn{2}{|c|}{ Before M\&A } & \multicolumn{2}{|c|}{ After M\&A } & \multirow{2}{*}{$\begin{array}{l}\text { Criticalratios } \\
\text { for coef. } \\
\text { difference } \\
|z|\end{array}$} \\
\hline & & Coef. & $p$-values & Coef. & p-values & \\
\hline \multicolumn{7}{|c|}{ Facebook (F): } \\
\hline $\mathrm{H}_{1}$ & Func $\rightarrow$ Awareness & 0.38 & $0.000^{*}$ & 0.44 & $0.000^{*}$ & 0.56 \\
\hline $\mathrm{H}_{2}$ & Func $\rightarrow P V$ & 0.57 & $0.000^{*}$ & 0.71 & $0.000^{*}$ & $2.43^{\dagger \dagger}$ \\
\hline $\mathrm{H}_{3}$ & $\mathrm{CS} \rightarrow$ Awareness & 0.10 & 0.321 & 0.07 & 0.448 & -0.19 \\
\hline $\mathrm{H}_{4}$ & $\mathrm{CS} \rightarrow \mathrm{PV}$ & 0.13 & $0.047^{*}$ & 0.16 & $0.011^{*}$ & 0.33 \\
\hline $\mathrm{H}_{5}$ & $\mathrm{PV} \rightarrow \mathrm{BE}$ & 0.75 & $0.000^{*}$ & 0.71 & $0.000^{*}$ & -1.09 \\
\hline $\mathrm{H}_{6}$ & Awareness $\rightarrow B E$ & -0.40 & $0.000^{*}$ & -0.22 & $0.010^{*}$ & 1.43 \\
\hline \multicolumn{7}{|c|}{ WhatsApp (W): } \\
\hline $\mathrm{H}_{1}$ & Func $\rightarrow$ Awareness & 0.63 & $0.000^{*}$ & 0.74 & $0.000 *$ & 1.45 \\
\hline $\mathrm{H}_{2}$ & Func $\rightarrow P V$ & 0.65 & $0.000^{*}$ & 0.78 & $0.000^{*}$ & $1.82^{\dagger \dagger}$ \\
\hline $\mathrm{H}_{3}$ & $\mathrm{CS} \rightarrow$ Awareness & -0.07 & 0.370 & -0.20 & $0.002^{*}$ & -1.31 \\
\hline $\mathrm{H}_{4}$ & $\mathrm{CS} \rightarrow \mathrm{PV}$ & 0.13 & $0.037^{*}$ & 0.15 & $0.022^{*}$ & 0.16 \\
\hline $\mathrm{H}_{5}$ & $\mathrm{PV} \rightarrow \mathrm{BE}$ & 0.64 & $0.000^{*}$ & 0.62 & $0.000^{*}$ & $-2.17^{\dagger \dagger}$ \\
\hline $\mathrm{H}_{6}$ & Awareness $\rightarrow \mathrm{BE}$ & -0.53 & $0.000^{*}$ & -0.12 & $0.000^{*}$ & $2.29^{t t}$ \\
\hline \multicolumn{7}{|c|}{ Micr osoft (M): } \\
\hline $\mathrm{H}_{1}$ & Func $\rightarrow$ Awareness & 0.81 & $0.000^{*}$ & 0.81 & $0.000^{*}$ & 0.79 \\
\hline $\mathrm{H}_{2}$ & Func $\rightarrow$ PV & 0.79 & $0.000^{*}$ & 0.77 & $0.000^{*}$ & 0.03 \\
\hline $\mathrm{H}_{3}$ & $\mathrm{CS} \rightarrow$ Awareness & 0.02 & 0.850 & 0.12 & 0.156 & -0.30 \\
\hline $\mathrm{H}_{4}$ & $\mathrm{CS} \rightarrow \mathrm{PV}$ & 0.03 & 0.706 & 0.14 & $0.046^{*}$ & 1.12 \\
\hline $\mathrm{H}_{5}$ & $\mathrm{PV} \rightarrow \mathrm{BE}$ & 0.71 & $0.000^{*}$ & 0.57 & $0.000^{*}$ & -0.85 \\
\hline $\mathrm{H}_{6}$ & Awareness $\rightarrow B E$ & -0.53 & $0.000^{*}$ & -0.47 & $0.009^{*}$ & $1.68^{t \dagger}$ \\
\hline \multicolumn{7}{|l|}{ Skype (S): } \\
\hline $\mathrm{H}_{1}$ & Func $\rightarrow$ Awareness & 0.72 & $0.000^{*}$ & 0.61 & $0.000^{*}$ & -1.16 \\
\hline $\mathrm{H}_{2}$ & Func $\rightarrow$ PV & 0.69 & $0.000^{*}$ & 0.57 & $0.000^{*}$ & -1.85 \\
\hline $\mathrm{H}_{3}$ & $\mathrm{CS} \rightarrow$ Awareness & -0.09 & 0.380 & 0.07 & 0.525 & 1.07 \\
\hline $\mathrm{H}_{4}$ & $\mathrm{CS} \rightarrow \mathrm{PV}$ & 0.25 & $0.000^{*}$ & 0.35 & $0.000^{*}$ & 1.04 \\
\hline $\mathrm{H}_{5}$ & $\mathrm{PV} \rightarrow \mathrm{BE}$ & 0.76 & $0.000^{*}$ & 0.73 & $0.000^{*}$ & -0.16 \\
\hline$\underline{\mathrm{H}_{6}}$ & Awareness $\rightarrow \mathrm{BE}$ & -0.54 & $0.000^{*}$ & -0.46 & $0.000^{*}$ & 0.56 \\
\hline
\end{tabular}

$\mathrm{p}<0.01 ; \mathrm{W}-$ Func $_{\mathrm{A}_{\mathrm{A}(\mathrm{Beffer})}}=0.63, \mathrm{p}<0.01, \mathrm{~W}-$ Func $_{\mathrm{A}(\mathrm{A} \text { After })}=0.74$, $\mathrm{p}<0.01 ; \mathrm{M}-$ Func $_{\mathrm{A}(\mathrm{Befure})}=0.81, \mathrm{p}<0.01, \mathrm{M}-\mathrm{Func}_{\mathrm{A}(\mathrm{A} \text { After })}=0.81$, $\mathrm{p}<0.01 ;$ S-Func $_{A_{(\text {B Befure })}}=0.72, \mathrm{p}<0.01$, S-Func $_{A(\text { Affer })}=0.61$, $\mathrm{p}<0.01)$. Therefore, $\mathrm{H}_{1}$ is not supported. $\mathrm{H}_{2}$ is not confirmed because the effect of product functionality on perceived brand value for each company is significant between before and after M\&A but the effects of after M\&A are bigger than before M\&A only existed in Facebook and WhatsApp (F-Func $\mathrm{FV}_{\mathrm{PB} \text { (Befre })}=0.57, \mathrm{p}<0.01, \mathrm{~F}$ Func $_{\mathrm{PV}(\text { After) }}=0.71, \mathrm{p}<0.01 ; \mathrm{W}-\mathrm{Func}_{\mathrm{PV}(\text { Befure })}=0.65, \mathrm{p}<0.01$, W-Func $\mathrm{PV}_{\mathrm{P}(\text { A A tet })}=0.78, \mathrm{p}<0.01 ; \mathrm{M}-\mathrm{Func}_{\mathrm{A}_{(\mathrm{B} \text { (Bfore })}}=0.79, \mathrm{p}<0.01$, M-Func $_{\mathrm{A}_{(\text {Affer })}}=0.77, \mathrm{p}<0.01 ; \mathrm{S}-$ Func $_{\mathrm{A}_{(\text {Before })}}=0.69, \mathrm{p}<0.01$, S-Func $\left.\mathrm{A}_{\mathrm{A}(\mathrm{A} \text { ftrt })}=0.57, \mathrm{p}<0.01\right)$. Regarding to $\mathrm{H}_{3}$, although, the effects of customer service on brand awareness of Facebook, Microsoft and Skype are insignificant between before and after $\mathrm{M} \& \mathrm{~A}\left(\mathrm{~F}-\mathrm{CS}_{\mathrm{A}(\mathrm{Beffure})}=0.10\right.$, $\mathrm{p}=0.321, \mathrm{~F}-\mathrm{CS}_{\mathrm{A}(\mathrm{A} \text { Aftr) }}=0.07, \mathrm{p}=0.448 ; \mathrm{M}-\mathrm{CS}_{\mathrm{A}(\text { Befire })}=0.02$, $\mathrm{p}=0.850, \mathrm{M}_{-} \mathrm{CS}_{\mathrm{A}(\mathrm{A} \text { Afer })}=0.12, \mathrm{p}=0.156 ; \mathrm{S}_{-\mathrm{CS}} \mathrm{S}_{\mathrm{A}(\mathrm{B} \text { efore })}=-0.09$, $\left.\mathrm{p}=0.380, \mathrm{~S}-\mathrm{CS}_{\mathrm{A}(\text { After })}=0.07, \mathrm{p}=0.525\right)$, a significant relationship in Whats App (W-CS A(Before) $_{\text {e }}=-0.07, \mathrm{p}=0.370$; $\left.\mathrm{W}-\mathrm{CS}_{\mathrm{A}(\mathrm{Aftrx})}=-0.20, \mathrm{p}<0.01\right)$. The improved effect is only in WhatsApp whose customer service does play an important role in influencing brand awareness in after M\&A. Hence, $\mathrm{H}_{3}$ is not supported. The effects of customer service on perceived brand value are improved for all four companies $\left(\mathrm{F}-\mathrm{CS}_{\mathrm{PV}(\text { Befure })}=0.13, \mathrm{p}<0.05\right.$, $\mathrm{F}_{-\mathrm{CS}} \mathrm{SV}_{\text {(Affer })}=0.16, \mathrm{p}<0.05 ; \mathrm{W}-\mathrm{CS}_{\mathrm{PV}(\mathrm{Beffare})}=0.13, \mathrm{p}<0.05$, $\mathrm{W}-\mathrm{CS}_{\mathrm{PV}(\text { Afftar })}=0.15, \mathrm{p}<0.05 ; \mathrm{M}-\mathrm{CS}_{\mathrm{PV}(\text { Befure })}=0.03, \mathrm{p}<0.706$, $\mathrm{M}-\mathrm{CS}_{\mathrm{PV}(\text { After })}=0.14, \mathrm{p}<0.05 ; \mathrm{S}^{-C S_{\mathrm{PV}(\mathrm{Beffore})}}=0.25, \mathrm{p}<0.01$, $\left.\mathrm{S}-\mathrm{CS}_{\mathrm{PV}(\text { A Afer })}=0.35, \mathrm{p}<0.01\right)$. It can be concluded that $\mathrm{H} 4$ is supported. Perceived brand value significantly affects brand equity in all four companies, but the effects of after M\&A are smaller than before M\&A for each company $\left(\mathrm{F} \mathrm{PV}_{\mathrm{BE} \text { (Before) }}=0.75, \mathrm{p}<0.01, \mathrm{~F}-\mathrm{PV} \mathrm{BE}_{\mathrm{BE}(\mathrm{A} \text { tert) }}=0.71, \mathrm{p}<0.01\right.$; $\mathrm{W}-\mathrm{PV}_{\mathrm{BE}(\text { (Beffre })}=0.64, \mathrm{p}<0.01, \mathrm{~W}-\mathrm{PV} \mathrm{BE}_{\mathrm{BE}(\text { After })}=0.62, \mathrm{p}<0.01$; $\mathrm{M}-\mathrm{PV} \mathrm{BE}_{\mathrm{BE}(\text { (Before })}=0.71, \mathrm{p}<0.01, \mathrm{M}-\mathrm{PV} \mathrm{VEE}_{\mathrm{BE}(\text { After })}=0.57, \mathrm{p}<0.01$; $\mathrm{S}-\mathrm{PV}_{\mathrm{BE}(\text { Before })}=0.76, \mathrm{p}<0.01, \mathrm{~S}-\mathrm{PV} \mathrm{BE}_{\mathrm{BE}(\mathrm{A} \text { Aftr) }}=0.73, \mathrm{p}<0.01$ ), not supporting $\mathrm{H}_{5}$. As hypothesized brand awareness plays a significant role in affecting brand equity for all four companies and the effect of after M\&A for each company is larger than before $\mathrm{M} \& \mathrm{~A}$ ( $\mathrm{F}-\mathrm{A}_{\mathrm{BE}(\mathrm{B} \text { efore })}=-0.40$, $\mathrm{p}<0.01, \mathrm{~F}-\mathrm{A}_{\mathrm{BE}(\mathrm{A} \text { After })}=-0.22, \mathrm{p}<0.05 ; \mathrm{W}-\mathrm{A}_{\mathrm{BE}(\text { Before })}=-0.53$, $\mathrm{p}<0.01, \mathrm{~W}-\mathrm{A}_{\mathrm{BE}(\text { Affer })}=-0.12, \mathrm{p}<0.01 ; \mathrm{M}-\mathrm{A}_{\mathrm{BE}(\text { Before })}=-0.53$, $\mathrm{p}<0.01, \mathrm{M}-\mathrm{A}_{\mathrm{BE}(\text { Affer })}=-0.47, \mathrm{p}<0.01 ; \mathrm{S}-\mathrm{A}_{\mathrm{BE}(\mathrm{Bef} \text { efre })}=-0.54$, $\left.\mathrm{p}<0.01, \mathrm{~S}-\mathrm{A}_{\mathrm{BE}(\text { After })}=-0.46, \mathrm{p}<0.01\right)$. H6 is confirmed.

Apart from the total (direct) effect showed in Table 2-5, it is still needed to consider the indirect effects of components on brand equity. These indirect effects are explored by adding the product functionality and customer service via. whole possible paths to brand equity. The AMOS results present that the all indirect effects of product functionality are larger than customer service on brand equity, even though part effects are not significant $\left(\mathrm{F}\right.$ Indieff $\mathrm{Func} \_$BE(Before) $=0.450 \mathrm{~F}$ Indieff $_{\text {CS_BE(Before })}=0.066$, F-Indieff $f_{\text {Func_BE(Affer })}=0.547>\mathrm{F}$ -

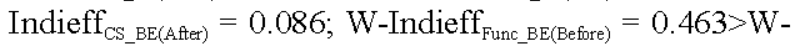
Indieff $_{\text {CS_BE(Before })}=0.086, \mathrm{~W}$-Indieff $f_{\text {Func_BE(AAfer })}=0.531>\mathrm{W}$ Indieff $_{\mathrm{CS}_{-} \mathrm{BE}(\text { AAfer })}=0.044 ; \mathrm{M}$-Indieff $\mathrm{Func} \_\mathrm{BE}($ Before $)=0.706>\mathrm{M}-$ Indieff $_{\text {CS_BE(Before })^{-}}=0.569, \mathrm{M}-$ Indieff $_{\text {Func_BE(After) }}=0.609>\mathrm{M}-$ Indieff $_{C_{C S B E(\text { Affer })}}=0.058 ;$ S-Indieff Func_BE(Before $)=0.445>\mathrm{S}-$ Indieff $_{\text {CS_BE(Befre) }}=0.124$, S-Indieff $f_{\text {Func_BE(After })}=0.419>\mathrm{S}-$ Indieff $_{\text {CS_BE(Affer) }}=0.180$ ) (Fig. 3-6).

The central aim of this study is to identify the drivers of brand equity, especially for the M\&A of online companies. The study provides new insights into important issues regarding brand equity and the exact direction in which to strengthen evaluation of M\&A of online companies. Most of the previous research on brand equity mainly dealt with analyzing the impact of unilateral antecedent on consumer evaluation without 


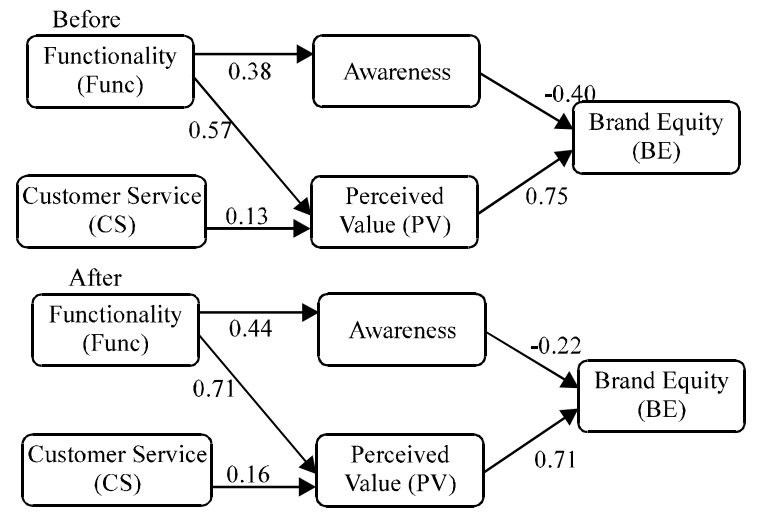

Fig. 3: Facebook before/after M\&A; only significant relationships are presented

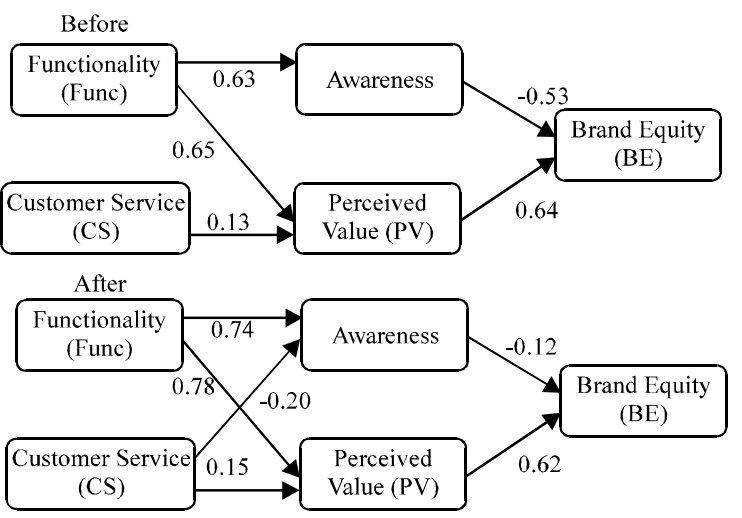

Fig. 4: WhatsApp before/after M\&A; only significant relationships are presented

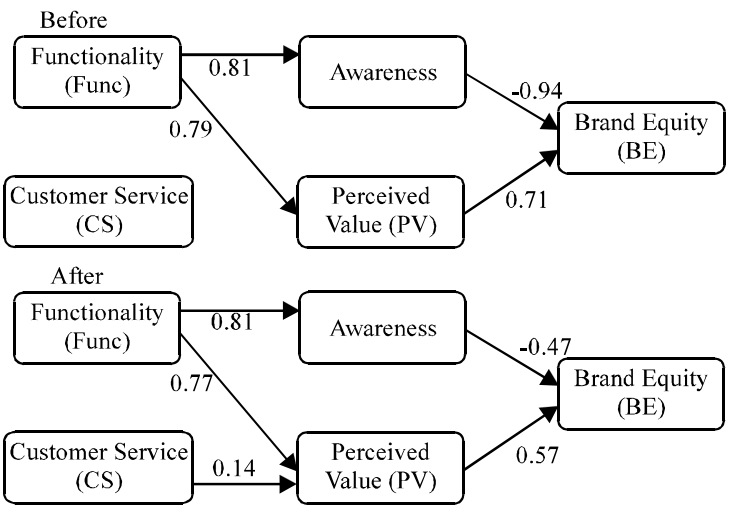

Fig. 5: Microsoft before/after M\&A; only significant relationships are presented

extending the different periods through which the same successful drivers of brand equity in before/after M\&A may impact consumer evaluation differently. By decomposing M\&A activities into two periods, this study

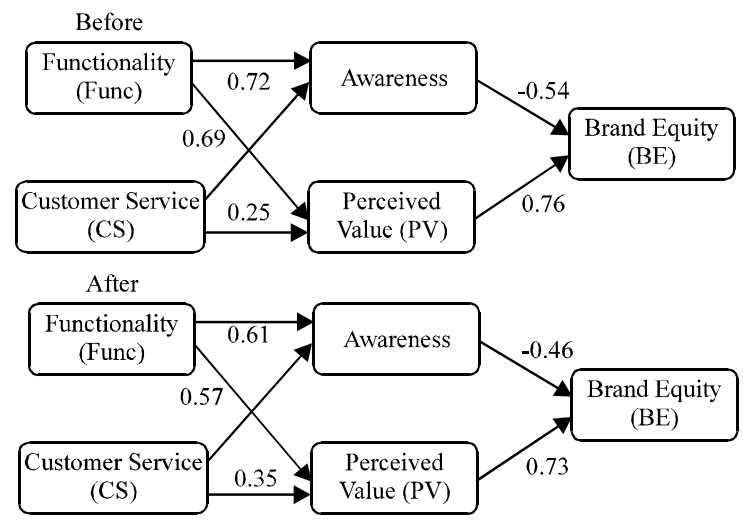

Fig. 6: Skype before/after M\&A; *only significant relationships are presented

sheds light on the subtle routes underlying consumer evaluation in the online company cases of brand equity between before and after M\&A.

It is hypothesized that brand equity, expressed both as before $M \& A$ versus after $M \& A$ and by the intention to re-evaluate from same companies would be influenced by consumers' brand awareness and perceived brand value towards it. As expected and by supporting some of the previous literature, brand awareness and perceived brand value are proven to be important sources of brand equity which coincides with the research of Keller (2003) and Rios and Riquelme (2010). The effects of brand awareness on brand equity in after M\&A are significantly larger than before M\&A in all 4 companies. However, consumer's perceived brand value toward brand equity exists opposite results which present that the effects of before M\&A are larger than the counterparts of after M\&A. It also shows that although consumers only have stronger evaluation about brand awareness on after M\&A, the effects are negative. Hence, regarding to the positive effects of perceived brand value and negative effects of brand awareness on brand equity, those 4 companies have to do further analyses about the synergy of the M\&A activities. Because every company has different kinds of backgrounds and M\&A activities, whether the M\&A activities create the comprehensive result is accurately the goal of the further research. In addition, it is worthy to notice that the importance of perceived brand value to the extent that total effect towards brand equity is larger than that of brand awareness. This result supports previous research of Yoo et al. (2000) who pointed out the existing, significantly weak relation between brand awareness and brand equity.

The results from both before and after M\&A of these companies also offer significant theoretical and managerial contributions to brand equity literature in 
several ways. Product functionality is an important component driving brand awareness and perceived brand value directly and building brand equity indirectly. However, the effect of product functionality on brand awareness and perceived brand value are improved in the case of Facebook and WhatsApp but not Microsoft and Skype. Probably consumers perceive that the identity of the two company is different. That is to say, the main business of Microsoft is the operation system and Skype is focusing on online communication. It is the construct with both improved effects on after M\&A which shows after M\&A, the brand awareness of 4 companies has significant improvements through this M\&A. Those results meet the results of Berry (2000) and Chiu and Wang (2000). The empirical results show that the effects of product functionality on perceived brand value in the case of Facebook and WhatsApp are stronger than it on brand awareness but not in the case of Microsoft-Skype. The results are partly consistent with Page and Lepkowska-White (2002)'s research which presents that online companies generally provide reliable functionalities increasing consumer's perceived brand value. Notwithstanding in this study no hypothesis are measured between product functionality and brand equity directly such effects are assessed by examining alternative paths in the empirical model and by checking the importance via. the indirect effect. The results confirm the importance of product functionality as indirect effects on brand equity via. brand awareness and perceived brand value. Hence, the importance of product functionality cannot be underestimated, even though few hypothesis in the case of Microsoft and Skype are not supported.

Customer service, the other interesting marketing component does not show consistent effects on brand awareness and perceived brand value. In terms of the effect on perceived brand value, all 4 companies exist improved effects after the M\&A activities. Regarding to the effect on brand awareness, there is only one significant effect in the case of after M\&A of WhatsApp even though this effect is negative. The rest of other effects are insignificant. It might be possible that consumers do not perceive that after M\&A, the acquirers on one hand do not need to help and integrate acquired companies to solve increased technical problems and relevant product problems from new consumers and on the other hand, acquired companies could not receive supports from acquirers that cause consumers to have less confidence towards their customer service. Therefore, it delivers three tasks for the managers at this situation. The first one is that because customer service largely influences perceive brand value but not brand awareness. Companies would put more effort to explore the efficient ways to enhance customer service in order to increase consumer's identification towards its perceived brand value. Second, it also might be the other way that through transferring company resources from customer service to other possible departments which can enhance its brand awareness and perceived brand value in the mind of the consumer. Certainly it needs to take deep business analyses to determine which business strategy is suitable for the company. Third, since, the product functionality practically affects both brand awareness and perceived brand value, how to improve and enhance product functionality of each product to receive consumer's identification would be a prominent issue for top managers.

\section{CONCLUSION}

In short, from the empirical results it is clear to understand that the M\&A of online companies could help companies enhance their brand equity.

\section{REFERENCES}

Aaker, D.A., 1991. Managing Rand Equity. Free Press, New York, USA., ISBN: 9780029001011 , Pages: 299.

Allaway, A.W., P. Huddleston, J. Whipple and A.E. Ellinger, 2011. Customer-based brand equity, equity drivers and customer loyalty in the supermarket industry. J. Prod. Brand Manage., 20: 190-204.

Alwi, S.F.S. and P.J. Kitchen, 2014. Projecting corporate brand image and behavioral response in business schools: Cognitive or affective brand attributes?. J. Bus. Res., 67: 2324-2336.

Askoul, R., H.U. Khan and V.M. Lalitha, 2016. Crossfunctional integration of marketing and information services in banking: A cross-industry comparison. Int. J. Process Manage. Benchmarking, 6: 57-78.

Awan, M.A. and H.U. Khan, 2016. Status of internet addiction among college students: A case of South Korea. Proceedings of the 1st American Academic Research Conference on Global Business, Economics, Finance and Social Sciences (AAR16 New York Conference), May 25-28, 2016, Wagner College, New York, USA., ISBN:978-1-943579-50-1, pp: $1-1$.

Awan, M.A., H.U. Khan and H.H. Chiang, 2016. Online banking: A comparative study of Chinese and Saudi customers perceptions of service quality. J. Internet Banking Commerce, 21: 1-31. 
Awan, M.A., H.U. Khan and W. Zhang, 2012. A comparative study on online service quality perception of two major regional economies. Intl. J. E. Educ. Bus. Manage. Learn., 2: 529-533.

Bagozzi, R.P. and Y. Yi, 1988. On the evaluation of structural equation models. J. Acad. Market. Sci., 16: 74-94.

Bamert, T. and P.P. Wehrli, 2005. Service quality as an important dimension of brand equity in swiss services industries. Manage. Service Qual., 2:132-141.

Bankole, O.A., V.M. Lalitha, H.U. Khan and A. Jinugu, 2017. Information technology in the maritime industry past, present and future: Focus on LNG carriers. Proceedings of the 2017 IEEE 7th International Conference on Advance Computing (IACC), January 5-7, 2017, IEEE, Hyderabad, India, ISBN:978-1-5090-1561-0, pp: 759-763.

Bashir, G.M. and H.U. Khan, 2016. Factors affecting learning capacity of information technology concepts in a classroom environment of adult learner. Proceedings of the 2016 15th International Conference on Information Technology Based Higher Education and Training (ITHET), September 8-10, 2016, IEEE, Istanbul, Turkey, ISBN:978-1-5090-0779-0, pp: 1-6.

Beerli, A., J.D. Martin and A. Quintana, 2004. A model of customer loyalty in the retail banking market. Eur. J. Market., 38: 235-275.

Berry, L.L., 2000. Cultivating service brand equity. J. Acad. Market. Sci., 28: 128-137.

Biedenbach, G. and A. Marell, 2010. The impact of customer experience on brand equity in a business-to-business services setting. J. Brand Manage., 17: 446-458.

Brock, V. and H.U. Khan, 2017. Big data analytics: Does organizational factor matters impact technology acceptance?. J. Big Data, 4: 1-28.

Brock, V.F. and H.U. Khan, 2017. Are enterprises ready for big data analytics? A survey based Approach. Int. J. Bus. Inf. Syst., 25: 256-277.

Burke, R.R., 2002. Technology and the customer interface: What consumers want in the physical and virtual store. J. Acad. Market. Sci., 30: 411-432.

Calder, B.J., L.W. Phillips and A.M. Tybout, 1981. Designing research for application. J. Consum. Res., 8: 197-207.

Casalo, L.V., C. Flavian and M. Guinaliu, 2010. Determinants of the intention to participate in firm-hosted online travel communities and effects on consumer behavioral intentions. Tourism Manage., 31: 898-911.
Chiu, C.H. and F.M. Wang, 2000. The influence of navigation map scope on disorientation of elementary students in learning a Web-based hypermedia course. J. Educ. Comput. Res.,22:135-144.

Cobb-Walgren, C.J., C. A. Ruble and N. Donthu, 1995. Brand equity, brand preference and purchase international. J. Advertising, 24: 25-40.

Das, A. and H.U. Khan, 2016. Security behaviors of smartphone users. Inf. Comput. Security, 24: 116-134.

E1 Halabi, A., A. Hachem, L. Al-Akhrass, H. Artail and H.U. Khan, 2014. Identifying the linkability between Web servers for enhanced internet computing. Proceedings of the 2014 17th IEEE Conference on Mediterranean Electrotechnical (MELECON), April 13-16, 2014, IEEE, Beirut, Lebanon, ISBN:978-1-4799-2337-3, pp: 1-5.

Fornell, C. and D.F. Larcker, 1981. Evaluating structural equation models with unobservable variables and measurement error. J. Market. Res., 18: 39-50.

Gholami, S., 2017. Assessing relationship quality elements by using the conceptual approach of CustomerBased Brand Equity (CBBE): A literature review. J. Eng. Appl. Sci., 12: 1060-1076.

Gill, M.S. and J. Dawra, 2010. Evaluating Aaker's sources of brand equity and the mediating role of brand image. J. Target. Meas. Anal. Marketing, 18: 189-198.

Gill, T. and J. Lei, 2009. Convergence in the high-technology consumer markets: Not all brands gain equally from adding new functionalities to products. Marketing Lett., 20: 91-103.

Gordon, R.J., 2010. Okun's law and productivity innovations. Am. Econ. Rev., 100: 11-15.

Gorsuch, R.L., 1983. Factor Analysis. 2ndEdn., L. Erlbaum Associates, Hillsdale, New Jersey, USA., ISBN:9780898592023, Pages: 425.

Hamzah, Z.L., S.F.S. Alwi and M.N. Othman, 2014. Designing corporate brand experience in an online context: A qualitative insight. J. Bus. Res., 67: 2299-2310.

Hassan, I.M., H.U. Khan and V.M. Lalitha, 2016. Pedagogical potentials of IEEE 802.11 WLAN to Nigerian universities: A case study of the university of Uyo. Int. J. Inf. Educ. Technol., 6: 256-261.

Hassan, I.M., H.U. Khan, R. Zeitun and G. Mardini, 2015. Pedagogical potentials of IEEE 802.11 WLAN to higher educational institutions: A case study of Nigerian based university. Proceedings of the 2015 IEEE 9th International Conference on Semantic Computing (IEEE ICSC 2015), February 7-9, 2015 , IEEE, Anaheim, California, ISBN:978-1-4799-7935-6, pp: $165-166$. 
Heang, J.F. and H.U. Khan, 2015. The role of internet marketing in the development of agricultural industry: A case study of China. J. Internet Commerce, 14: 65-113.

Ho, H.C., M.A. Awan and H.U. Khan, 2016. Luxury brands and corporate responsibility: A perspective on consumer's preferences. J. Int. Manage. Stud., 16: 77-81.

Keller, K.L. and D.R. Lehmann, 2003. How do brands create value?. Marketing Manage., 12: 26-31.

Keller, K.L., 2003a. Strategic Brand Management: Building, Managing and Measuring Brand Equity. 2nd Edn., Prentice Hall, New Jersey.

Keller, K.L., 2003b. Strategic Brand Management: Building, Measuring and Managing Brand Equity. 2nd Edn., Prentice-Hall, New York, ISBN-13: 9780131006706, Pages: 788.

Khan, H.U. and A. Alhusseini, 2015. Optimized web design in the Saudi culture. Proceedings of the 2015 Conference on Science and Information (SAI), July 28-30, 2015, IEEE, London, UK., ISBN:978-1-4799-8547-0, pp: 906-915.

Khan, H.U. and A.C. Ejike, 2017. An assessment of the impact of mobile banking on traditional banking in Nigeria. Int. J. Bus. Excellence, 11: 446-463.

Khan, H.U. and M.A. Awan, 2017. Possible factors affecting internet addiction: A case study of higher education students of Qatar. Int. J. Bus. Inf. Syst., 26: 261-276.

Khan, H.U. and O.A. Adediji, 2017. Need for RADAR system utilisation for maritime traffic management: A case of Congo River Basin. Int. J. Computat. Syst. Eng., 3: 163-174.

Khan, H.U. and S. Uwemi, 2018a. Possible impact of E-commerce strategies on the utilisation of E-commerce in Nigeria. Intl. J. Bus. Innovation Res., 15: $231-246$.

Khan, H.U. and S. Uwemi, 2018b. What are E-commerce possible challenges in developing countries: A case study of Nigeria. Intl. J. Bus. Syst. Res., 12: 454-486.

Khan, H.U. and Y. Gadhoum, 2018. Measuring internet addiction in arab based knowledge societies: A case study of Saudi Arabia. J. Theor. Appl. Inf. Technol., 96: 1500-1518.

Khan, H.U., 2012. Computer mediated communication, quality of learning and performance. J. GSTF. Bus. Rev., 1: 81-88.

Khan, H.U., 2013. Role of computer mediated communication in affect empowerment and performance improvement. Int. J. Comput., 3: 165-171.

Khan, H.U., 2013. Use of e-learning tools to solve group work problems in higher education: A case study of gulf country. Adv. Comput. Sci. Int. J., 2: 90-96.
Khan, H.U., 2016. Possible effect of video lecture capture technology on the cognitive empowerment of higher education students: A case study of gulf-based university. Int. J. Innov. Learning, 20: 68-84.

Khan, H.U., H.A. Artail, Z. Malik and M. Niazi, 2014. Information technology adoption, possible challenges and framework of supply chain management: A case study of a leading gulf economy. Proceedings of the 2014 4th International Conference on Engineering Technology and Technopreneuship (ICE2T), August 27-29, 2014, IEEE, Kuala Lumpur, Malaysia, ISBN: 978-1-4799-4621-1, pp: 1-5.

Khan, H.U., M.A. Awan and H.C. Ho, 2014. How do Chinese and Saudi customers perceive online service quality? A comparative study. J. Bus. Inquiry: Res. Educ. Applic., 13: 142-157.

Khan, H.U., O.A. Bankole and M.K. Alomari, 2017. Possible effect of IT introduction into the election process: A case study of Nigeria. Int. J. Bus. Forecasting Marketing Intell., 3: 109-129.

Khan, H.U., S. Ahmad and M. Abdollahian, 2013. Supply chain technology acceptance, adoption and possible challenges: A case study of service organizations of Saudi Arabia. Proceedings of the 2013 10th International Conference on Information Technology: New Generations (ITNG), April 15-17, 2013, IEEE, Las Vegas, Nevadapp, ISBN:978-0-7695-4967-5, pp: 590-595.

Khan, H.U., V.M. Lalitha and J.F. Omonaiye, 2017. Employees' perception as internal customers about online services: A case study of banking sector in Nigeria. Int. J. Bus. Innov. Res., 13: 181-202.

Klaus, P.P. and S. Maklan, 2013. Towards a better measure of customer experience. Intl. J. Market Res., 55: 227-246.

Lee, H.M., C.C. Lee and C.C. Wu, 2011. Brand image strategy affects brand equity after M\&A. Eur. J. Marketing, 45: 1091-1111.

Musa, A., H.U. Khan and K.A. AlShare, 2015. Factors influence consumers' adoption of mobile payment devices in Qatar. Intl. J. Mobile Commun., 13: 670-689.

Najmi, E., K. Hashmi, Z. Malik, A. Rezgui and H.U. Khan, 2015. CAPRA: A comprehensive approach to product ranking using customer reviews. Computing, 97: 843-867.

Omonaiye, J.F., V.M. Lalitha, H.U. Khan, S.D. Fournier-Bonilla and R. Singh, 2015. Ability and hurdle to provide banking online services: A case study of banking employees in Nigeria. Proceedings of the 2015 IEEE 2nd International Conference on Cyber Security and Cloud Computing (CSCloud), November 3-5, 2015, IEEE, New York, USA., ISBN:978-1-4673-9299-0, pp: 482-487. 
Page, C. and L. Lepkowska-White, 2002. Web equity: A framework for building consumer value in online companies. J. Consum. Market., 19: 231-248.

Ratnatunga, J. and M.T. Ewing, 2009. An ex-ante approach to brand capability valuation. J. Bus. Res., 63: 323-331.

Rios, R.E. and H.E. Riquelme, 2008. Brand equity for online companies. Marketing Intell. Plann., 26: 719-742.

Rios, R.E. and H.E. Riquelme, 2010. Sources of brand equity for online companies. J. Res. Interact. Market., 4: $214-240$.

Simon, C.J. and M.W. Sullivan, 1993. The measurement and determinants of brand equity: A financial approach. Market. Sci., 12: 28-53.

Smuts, R.G., V.M. Lalitha and H.U. Khan, 2017. Change management guidelines that address barriers to technology adoption in an HEI context. Proceedings of the 2017 IEEE 7th International Conference on Advance Computing (IACC), January 5-7, 2017, IEEE, Hyderabad, India, ISBN:978-1-5090-1561-0, pp: 754-758.

Srinivasan, K., L. Shiue, J.D. Hayes, R. Centers and S. Fitzwater et al., 2015. Detection and measurement of alternative splicing using splicing-sensitive microarrays. Methods, 37: 345-359.
Supphellen, M. and H. Nysveen, 2001. Drivers of intention to revisit the websites of Well-known companies: The role of corporate brand loyalty. Intl. J. Market Res., 43: 341-352.

Sweeney, J.C. and G.N. Soutar, 2001. Consumer perceived value: The development of a multiple item scale. J. Retail., 77: 203-220.

Thompson, B., 2000. Ten Commandments of Structural Equation Modeling. In: Reading and Understanding more Multivariate Statistics, Grimm, L.G. and P.R. Yarnold (Eds.). American Psychological Association, Washington, DC., USA., pp: 262-283.

Thompson, B., 2000. Ten Commandments of Structural Equation Modeling. In: Reading and Understanding more Multivariate Statistics, Grimm, L.G. and P.R. Yarnold (Eds.). American Psychological Association, Washington, DC., USA., pp: 262-283.

Vu, D.A. and O.I. Moisescu, 2013. Brand integration practices in mergers and acquisitions. Manage. Marketing, 8: 403-428.

Yoo, B., N. Donthu and S. Lee, 2000. An examination of selected marketing mix elements and brand equity. J. Acad. Market. Sci., 28: 195-211.

Zeithaml, V.A., 1988. Consumer perceptions of price, quality and value: A means-end model and synthesis of evidence. J. Market., 52: 2-22. 